\title{
IMPROVEMENT ANALYSIS OF LEARNING VOCABULARY ASSISTED WITH FLASH CARDS
}

\author{
Srundi Akbar Zaenuri ${ }^{1}$, Nur Alamsyah ${ }^{2}$ \\ ${ }^{1}$ IKIP Siliwangi \\ ${ }^{2}$ IKIP Siliwangi \\ ${ }^{1}$ akbar.srundi@gmail.com, ${ }^{2}$ Noeralamsyah0000@gmail.com
}

\begin{abstract}
Vocabulary is a very important part of learning English that must be mastered by students to communicate well. This research try to analyze (1) discussions that often occur in pronunciation of vocabulary for students using the flash cards method; (2) implementing learning to read vocabulary in speaking skills; (3) learning evaluation system for pronunciatioln of vocabulary for students using the flash cards method; (4) Improving pronunciation skill words to students through the flashcard method. The method used in this research was classroom action research (CAR). The research method also aims to memorize quickly the vocabulary they receive is important vocabulary they want for the continuity of learning English using the flashcard method. The results showed that students' vocabulary understanding improved after they were taught using flash cards
\end{abstract}

Keywords: Vocabulary,Flashcard, CAR

\section{INTRODUCTION}

Vocabulary as the main learning in the language of each language. Laura (1997) says that vocabulary is the main learning that is very important in the preparation of the language spoken by Komachali (2012). Folse (2004) Hunt \& Belgar (2005) says that there are several studies conducted in the field of vocabulary learning and Groot (2006) looking for the most effective way of learning vocabulary that is still unclear (Komachali, 2012).

Basic aim of language learning nowdays is communication and vocabulary plays an important role in conversation (Komorowska, 2005) as cited in Nurdiansyah, Asyid \& Parmawati (2019). Hedge (2008) Richards \& Renandya (2002) says that vocabulary has always been a language learning that is often ignored in English literature and often teachers who are rejected will learn vocabulary that must be repeated frequently in learning. Vocabulary that is often given few priorities, programs in, language lessons and is often permitted by itself to only get a minimum in English textbooks (Mohammad, 2014). Nation (2008) said in advance vocabulary learning is not too important as time goes by humans understand why the importance of the word vocabulary in language learning (Alemi, 2011). Griffiths (2006) also said in a quote (Alemi, 2011) currently asking for vocabulary lessons to be realized.

Very often do we find students who will have difficulty applying this vocabulary in English? or compilation of questions and answers he knows what answers only do not know what vocabulary to use and sometimes the compilation of pronunciation of words is not right between writing and pronunciation. 
Brown (2000) says there are many ways to improve the learning of words with the flash card method. The advantage of using the flash card method can be applied regardless of the time and place they can use this method anytime and anywhere (Abbasian, 2016). Gairns \& Redman (1990) have an opinion that the group will create a new vocabulary that they will know (Abbasian, 2016). Nation (2001) says when students fail to learn new vocabulary they will be disappointed and not confident (Alqahtani, 2015). there needs to be a motivation for students to continue to learn vocabulary in any way, one of them is flash cards.

Vocabulary learning using flashcards is still very rare therefore researchers must be careful in using this method. Vocabulary is a very important part of learning English that must be mastered by students to communicate well. Hatch \& Brown (1995: 1) defines that vocabulary as list or word regulator for a particular language or list or words that can be used by each language speaker. Vossoughi (2009: 1) states that words are tools which can always be used to think, to improve ideas and feelings, and to learn about the World. Templeton (2004) defines the vocabulary used and understood by students. Based on the previously issued resolution of the vocabulary is a set of written and oral learning that is made and used to be spoken or communicated in the learning language as quoted (Ump, 2010).

Westwood, Peter and Oliver (1979) say some become principles in language pronunciation if the learning of language teaching vocabulary programs is based on the following:
a. creating a learning situation that is fun, entertaining, giving pleasure to students;
b. maintaining work activities for a lifetime;
c. arrange a short intensive session every day;
d. ensuring students actively remember the vocabulary learned in order to improve communication skills;
e. has goals for the future
f. pay attention to all students, both active and inactive students;
g. using methods to attract students' attention while learning;
h. provide motivation so students can be enthusiastic to learn (Rambe, 2016).

\section{Vocabulary}

Vocabulary is a list of words in a language to communicate (Joklova, 2009). Vocabulary learners are very important because of the need to achieve a good communication in any language, especially academic needs (Komachali and Khodareza, 2012). Vocabulary learning can be applied in daily activities anywhere in order to achieve good success tagers (Manorek 2018). 


\section{Flashcard}

A flash card is a method that can make cardboard, paper or anything consisting of simple words, sentences or drawings (Eslahcar, 2012: 137) as in cited (Komachali, 2012). In addition, Cross (1991) cited in Farida, Isrina \& Apsari (2019), flashcards is a simple picture on the piece of card or paper, and usually this media always used as a education tools. Moreover, Based on www.wikipedia.com flash cards are information card inside both sides and colors, used in the classroom or in private study. In this study, the limit of the size of flash cards which are used. The flash cards print off onto 8.5 "X 11 " $(21.59 \mathrm{~cm}$ X $27.94 \mathrm{~cm})$. This is very important for flash cards because they are bright, bold, attractive, and engaging. Moreover, I use plastic laminating of the flash cards so All can last even with regular use, or can be obtained on websites that are already available for printing so that it's easier for teachers obtain them.

\section{METHOD}

The method used in this research was classroom action research(CAR) focused on improve vocabulary learning skills using flash card. The subjects of this study consist of 20 students from first class of Tunas Mekar Karawang Vocational School.

To collect data, the instruments used by the pre-test and post-test of each research student gave 30 vocabulary words in Indonesian and translated into English, then the a researcher gave lessons to use flashcards to each student to be able to memorize them well. And observation. Tests after the first treatment and tests after the second treatment were given to determine the increase in vocabulary skills of students, formative tests were given to measuring testing increase in their vocabulary skills from cycle 1 and cycle 2 . Observations were given to measure student characteristics of applications using flash cards and questionnaires were given to support data on increasing students in vocabulary English skills.

\section{RESULTS AND DISCUSSION}

\section{Results}

The assessment is used to see the improvement in students' vocabulary skills (Banigau, 2008):

\begin{tabular}{llllll} 
& \multicolumn{2}{l}{ First treatment } & \multicolumn{2}{l}{ Second treatment } & Priteri \\
\cline { 2 - 5 } Interval & $\begin{array}{l}\text { Number } \\
\text { of } \\
\text { Students }\end{array}$ & Percentages & $\begin{array}{l}\text { Number } \\
\text { of } \\
\text { Students }\end{array}$ & Percentages & \begin{tabular}{l} 
a \\
\hline $80-100$
\end{tabular} \\
\hline $70-79$ & 12 & 0.0 & 11 & 55.0 & $\begin{array}{l}\text { Very } \\
\text { Good }\end{array}$ \\
\hline
\end{tabular}




\begin{tabular}{llllll}
$56-69$ & 8 & 40.0 & 1 & 5.0 & Fair \\
\hline $45-55$ & 0 & 0.0 & 0 & 0.0 & Less \\
\hline $0-44$ & 0 & 0.0 & 0 & 0.0 & Poor \\
\hline Total & 20 & 100 & 20 & 100 &
\end{tabular}

\section{Discussion}

Based on the results of these activities, here researchers can find out in advance how much vocabulary students know. And using the flashcard method can provide students with more vocabulary knowledge which makes them enthusiastic in learning English, especially in memorizing vocabulary

\section{CONCLUSION}

This study examines vocabulary learning by using the flash card method as a strategy in comparing students before learning and after learning. The results showed that students' vocabulary understanding improved after they were taught using flash cards. Students recognize when learning with motede is very easy to quickly understand and be a motivation for them to continue to want to learn.

There are a number of suggestions for this research in the field of teaching vocabulary using flash cards. First, it is recommended for further studies to conduct research in other contexts, such as reading, writing, speaking, listening and teaching grammar. Secondly, it is suggested that teachers can present interesting images on flash cards to lead better teacher performance and not make children bored. Third, if the teacher uses the word list as a strategy for teaching vocabulary, he can create a fun learning process, such as playing games. Overall, it is recommended to use flash cards as a strategy for teaching vocabulary to young students.

\section{ACKNOWLEDGMENTS}

In this paper we would like to express my gratefullness who people helped, guided, and supported in writing and finishing this paper.

\section{REFERENCES}

Abbasian, G. (2016). The Effect Of Flash Card-Based Instruction On Vocabulary Learning By Efl Learners. 1929-1938.

Alemi, M. (2011). The Influence Of Incidental And Intentional Vocabulary Acquisition And Vocabulary Strategy Use On Learning L2 Vocabularies. 2(1), 81-98. Https://Doi.Org/10.4304/J1tr.2.1.81-98

Alqahtani, M. (2015). The Importance Of Vocabulary In Language Learning And How To Be Taught. Iii(3), 21-34. Https://Doi.Org/10.20472/Te.2015.3.3.002

Banigau, R. W. (2008). Improving Vocabulary Ability By Using Comic.

Farida, D., Isrina, H. D., \& Apsari, Y. (2019). The Implementation Of Flash Cards To Improve 
Students'vocabulary Mastery. Project (Professional Journal Of English Education), 2(3), 352-357.

Komachali, M. E. (2012). The Effect Of Using Vocabulary Flash Card On Iranian PreUniversity Students " Vocabulary Knowledge. 5(3), 134-147. Https://Doi.Org/10.5539/Ies.V5n3p134

Manorek, M. (N.D.). Using Charades Technique To Increase Students' Vocabulary At Smp Kristen Rurukan. 1-5.

Mohammad, A. (2014). Vocabulary: Challenges And Debates Vocabulary: Challenges And Debates. (May). Https://Doi.Org/10.5539/Elt.V3n3p89

Nurdiansyah, D. M. R., Asyid, S. A., \& Parmawati, A. (2019). Using Color Coding To Improve Students'english Vocabulary Ability. Project (Professional Journal Of English Education), 2(3), 358-363.

Rambe, R. (2016). The Implementation Of Picture Series Media To Improve Pgmil's Students Ability In Speaking. Vi(1).

Ump, F. (2010). The Effectiveness Of Pictionary Game..., Aliy Nugroho Setiyajid, Fkip Ump, 2015. 